\title{
Ibrahim M. Abu Rabi' Tentang Respon Islam dan Kritik Historis
}

\author{
Chafid Wahyudi \\ STAI Al-Fithrah Surabaya \\ hafiz_why@yahoo.co.id
}

\begin{abstract}
This article departs from Ibrahim Abu Rabi's criticism of the negative western view of Islam. Islam has been labeled by the west as radical, terrorist, anti-Western, antidemocratic and others. On the other hand, Abi Rabi' wants to show that there are complexities in Islam, one of which is because of colonialism. As a result, there were various Islamic responses to colonialism. Abu Arabi' noted that there were three responses, namely modernization, nationalism, and religious revivalism. He saw the emergence of Islamic movements as a response to colonialism in several Muslim countries that failed to create good modernization, such as education and democracy. To open up modernization, especially in Islamic education, Abu Rabi' offers a historical criticism approach by understanding inclusive theology, the dominance of texts and religion as social-anthropological facts. The combination of these various approaches becomes Abu Rabi's offer as a historical critique of Islam.
\end{abstract}

Keywords: colonialism, modernism, historical criticism

\section{Pendahuluan}

Islam sendari awal mengalami citra yang peyoratif. Di era kontemporer, tragedi 11 Sepetember 2001, atau peristiwa yang dikenal Black Thursday of September setidaknya menjadi salah satu penanda bagaimana Barat memandang negatif atas 
Islam. Islam tertuduh sebagai agama di mana penganutnya dalah radikal, teroris, anti-Barat, menolak demokrasi dan lain-lain. Pendek kata Islam, adalah liyan yang mengancam Barat. Persis seperti yang diungkap Samuel Huntington yang pada tahun 1993, yang menggulirkan teori tentang perang peradaban, (The Clash of Civilizations) Islam dan Barat yang di dalamnya mendesain Islam sebagai ancaman terbesar bagi Barat. ${ }^{1}$

Pandangan Barat atas Islam tersebut menjadi inspirasi Pusat Pengambilan Keputusan AS sebagaimana dilangsir dalam tulisan utama The New York Times, pada 1996, dengan lantang memberi judul "Seeing Green: The Red Menace Is Gone. But Here's Islam” (Momok Hijau: Bahaya Merah Telah Berlalu. Tetapi Sekarang Islam). ${ }^{2}$ Pesan penting dalam tulisan tersebut adalah bahaya Komunis telah berlalu, sekarang bahaya itu hadir dalam bentuk lain, yaitu agama Islam.

Berpijak kegelisahan tersebut, M. Abu Rabi' terpanggil untuk menjelaskan atas tuduhan Barat kepada Islam. Dalam salah satu artikelnya, ia mengemukakan bahwa tragedi 11 September, entry point-nya tidak bisa dilepaskan dari dominasi Barat dan dampaknya terhadap dunia Islam modern, khususnya Amerikanisasi telah menjadi ideologi terkemuka di dunia, terutama sejak runtuhnya sistem Soviet di akhir 1980-an. ${ }^{3}$ Karenanya, menurut Abu Rabi' yang harus dilakukan adalah kajian historis pada dinamika politik, sosial, dan keagamaan di dunia Islam modern yang dilatarbelakangi kolonialisasi, kemerdekaan negara, dan kelelahan akan proyek nasionalis di banyak Negara Arab dan Muslim. ${ }^{4}$

Berdasarkan hal tersebut, tulisan ini mencoba mengakses inti poin pemikiran Abu Rabi' serta tawaran kritik historis dalam studi Islam.

\section{Sekilas Perjalanan Intlektual Ibrahim M. Abu Rabi’}

Ibrahim M. Abu-Rabi' terlahir di Nazareth Galilea, Palestina pada tahun 1956. Ia meninggal di Amman Yordania, 2 Juli 2011, di usia 56 tahun karena serangan

\footnotetext{
${ }^{1}$ Samuel Hutington, The Clash of Civilizations and the Remaking of World Order (New York: Simon and Schuster, 1996).

${ }^{2}$ Bruce B. Lawrence, Islam Tidak Tungggal: Melepaskan Islam Dari Kekerasan, terj. Harimukti Bagoes Oka (Jakarta: Serambi Ilmu Semesta, 2004), 9-10.

${ }^{3}$ Ibrahim M. Abu Rabi', “A Post-September 11 Critical Assessment of Modern Islamic History”, dalam September 11: Relegious Perspectives On the Causes and Consequences, Ian Markham and Ibrahim M. Abu-Rabi (eds.) (England: Hartford Seminary, 2002), 20.

${ }^{4}$ Ibid.
} 


\section{Chafid Wahyudi}

jantung. Ia memiliki dua kewarganegaraan, yakni Amerika Serikat dan Israel. ${ }^{5}$ Setelah menyelesaikan pendidikan dasar di kota kelahirannya, Abu Rabi menempuh pendidikan sarjana di Universitas Birzeit, Palestina di bidang Seni dan diselesaikan pada tahun 1980. Dua tahun berikutnya, tahun 1982, ia merampungkan Magisternya di bidang Ilmu Politik pada Universitas Cincinnati. Setahun kemudian, gelar Magister kedua ia selesaikan di Temple University Pennsylvania, tahun 1983. Di universitas yang sama, ia meraih gelar PhD di bidang Studi Islam pada tahun 1987. Pada tahun 1991, Abu Rabi' dianugrahi Guru Besar Studi Islam dan Hubungan Kristen-Muslim di Duncan Black Macdonald pada Hartford Seminary. ${ }^{6}$

Abu Rabi' termasuk sosok yang aktif mengajar. Terbukti ia mendedikasikan mengajarnya di berbagai intitusi mancanegara, antara lain; Virginia Commonwealth University, Temple University di Pennsylvania, Universitas Cincinnati, Universitas Texas di Austin, Uni Theological Seminary di New York City, Institut Tantur Ekumenis di Yerusalem Israel, Al-Fatih Al-Islami Institute di Damaskus Suriah, Institut Becket di Oxford University, Institut Internasional Pemikiran Islam dan Peradaban (ISTAC) di Kuala Lumpur Malaysia, Universitas Islam Internasional di Daru El-Ehsan Malaysia. Pada tahun 2006, ia adalah Senior Fulbright Scholar di Singapura dan Indonesia di Institute of Defence and Strategic Studies di Nanyang Technological University Singapura. ${ }^{7}$

Selain dedikasi mengajar, Abu Rabi' adalah sosok penulis produktif, termasuk sebagai editor buku-buku ilmiah. Mengenai karya-karya Abu Rabi' dapat diakses pada International Council for Midle East Study, Ibrahim M. Abu Rabi' $\left(1956-2011 .^{8}\right.$

\section{Beragam Respon Islam Terhadap Dunia Barat}

Relasi Muslim dan Kristen (Barat-Eropa) identik dengan konfrontasi, dan itu berjalan secara kesinambungan. Akhir abad ke $7 \mathrm{M}$, Islam mengawali ekspansinya, dan menguasai hampir seluruh kawasan Laut Tengah -dari Anatolia (Turki)

\footnotetext{
${ }^{5}$ Duncan Black for Macdonald Cente, Faculty Profile of Ibrahim M. Abu Rabi', http://macdonald.hartsem. edu /aburabi.htm, diakses 31 Oktober 2013.

${ }^{6}$ Lihat International Council For Middle East Studies, Ibrahim M. Abu Rabi' (19562011), http://www.icmes.net/?page id=353, diakses 31 Oktober 2013

${ }^{7}$ International Council For Middle East Studies, Ibrahim M. Abu Rabi' (1956-2011)

${ }^{8}$ Lihat di International Council for Midle East Study, Ibrahim M. Abu Rabi' (19562011), http://www.icmes.net/?page id=353, diakses 31 Oktober 2013.
} 
hingga selat Gibaltral, kemudian melebar ke semenanjung Iberia dan menguasai kawasan Pyrenia. Setelah fase tersebut terjadi Perang Salib di Timur Tengah selama 2 abad (1095-1291), berakhir dengan kemenangan muslim di mana laskar Salib berhasil diusir dari Palestina. Abad berikutnya, Pada tahun 1396, tentara Kristen dalam jumlah besar menyerbu Turki Utsmani, untuk memperebutkan Konstantinopel pada 1453 . $^{9}$

Babak berikutnya, Abu Rabi' mencatat tiga peristiwa penting atas identifikasi Barat Eropa sebagai Eropa modern; pertama; penaklukan Turki Utsmani atas Konstantinopel, kedua, pengusiran besar-besaran masyarakat muslim di Spanyol; Ketiga penemuan benua baru Eropa oleh Columbus. ${ }^{10}$ Babakan ini menjadi arus balik, khususnya penemuan Columbus atas benua baru menjadi jalan pembuka kolonialisme maupun imprialisme Eropa ke negara-negara Islam maupun dunia ketiga. Mengutip Benedict Anderson, Abu Rabi' menyebut kolonialisasi Eropa dimulai dari Spanyol dan Portugis pada akhir masa feodalisme abad ke 16. Menyusul kemudian pada abad 17, Belanda menguasai perdagangan. Di masa Pencerahan abad 18, Inggris terlibat kolonialisasi. Puncak kolonialisasi terjadi pada abad 19 di masa industrialisasi, Prancis dan negara-negara Eropa lainnya berlomba-lomba menemukan koloni baru. Tidak ketinggalan Amerika dengan motorized di abad $20 .^{11}$

Gempuran kolonialisme menjadikan pengaruh kekuatan dunia Islam melemah. Dalam pandangan Abu Rabi', imbas kolonialisasi yang mejadikan dunia Islam lemah karena penguasa pemerintahan Islam saat itu stagan, tidak mampu mengantisipasi perkembangan dengan modernisasi masyarakat, sebaliknya perluasan kolonialisasi Eropa tidak lepas dari internal Eropa yang dikenal renaissance. Dengan kata lain, kolonisasi di dunia muslim, khususnya pada abad ke-19 merupakan fakta atas stagnasi internal Islam di satu sisi, disisi lain kemenangan model masyarakat dan ekonomi Eropa. ${ }^{12}$

Meski demikian, bukan berarti dunia Islam tidak merespon dominasi Eropa, memasuki abad ke-18 dan ke-19, gerakan Islam mulai bermunculan. Gerakangerakan ini berusaha untuk merekonstruksi baik pada level lembaga keagamaan, sosial, politik, maupun ekonomi dunia Islam modern. Abu Rabi' mencatat respon

\footnotetext{
${ }^{9}$ Azyumardi Azra, Pergolakan Politik Islam; dari Fundamentalisme, Modernitas hingga PostModernisme (Jakarta: Paramadina, 1996), 196, 200-201.

${ }^{10}$ Abu Rabi', "A Post-September 11, 22-23.

${ }^{11}$ Ibid., 22.

${ }^{12}$ Ibid., 23.
} 


\section{Chafid Wahyudi}

tersebut paling tidak dapat diidentifikasi dalam tiga gerakan: modernization, nationalism, dan religious revivalism. ${ }^{13}$

\section{Modernisasi}

Salah satu respos ambisius atas Eropa datang dari Turki Utsmani di awal abad ke19. Respon ambisius dikenal dengan Tanzimat (1839-1876 M). ${ }^{14}$ Sebuah proyek modernisasi yang didukung penuh oleh para ulama/intektual, elit politik, birokrat dan militer. Mereka menyadari betul upaya tersebut jika ingin mempertahankan kekuasaan Turki Utsmani. ${ }^{15}$ Upaya yang sebenarnya pernah dilakukan oleh Sultan Ahmad II (1703-1730) dan Sultan Salim III (1789-1807) hingga Sultan Mahmud II (1785-1839). Jika Sultan Ahmad II fokus modernisasi di bidang militer, maka Sultan Salim III memodernisasi di segala bidang. Sayangnya, modernisasi yang lakukan mendapat tantangan keras dari para ulama dan militer. Bahkan Sultan Salim III mengalami kudeta. Selanjutnya Sultan Mahmud II meneruskan proyek pendahulunya. Sultan Mahmud II mulai terbuka dan beroreitasi ke Eropa, khususnya di bidang pendidikan. Catatan penting pada masa Sultan Mahmud II adalah modernisasi dilakukan nyaris tidak ada oposisi dikarenakan kepemerintahannya menjalankan secara otoriter. Para oposisi dilemahkan dan dihancurkan. ${ }^{16}$

Meski berbagai upaya modernisasi telah dilakukan oleh Turki Utsmani, namun upaya tersebut tidak mampu mempertahankan eksistensi kerajaan Turki Utsmani. Tepat diakhir perang dunia pertama (1914-1918), kerajaan Turki Utsmani akhirnya tumbang setelah berkuasa hampir tujuh abad. ${ }^{17}$ Usaha modernisasi yang gagal menyelamatkan Turki Utsmani tersebut, memberi inspirasi sebagian intelektual guna menghadirkan semangat sekularistik. Bagi sebagian intelektual, satu-satunya solusi menghindari keterpurukan dan keterbelakangan adalah dengan jalan copy paste Westernisasi. ${ }^{18}$

\footnotetext{
${ }^{13}$ Ibid.

${ }^{14}$ Tanzimat adalah upaya Reorganisasi. Secara behasa berarti "mengatur", "menyusun”, dan "memperbaiki". Nina M. Armando (ed.), Ensiklopedi Islam (Jakarta: Ichtiar Baru van Hoeve, 2005), jilid VII, 69.

${ }^{15}$ Abu Rabi', “A Post-September 11”, 24

${ }^{16}$ Ira M. Lapidus, A. History of Islamic Societies (New York: Cambridge University Press, 1983), 589.

${ }^{17}$ Ibid., 595-6.

${ }^{18}$ Abu Rabi', “A Post-September 11”, 24
} 
Salah satu yang terinspirasi semangat Westernisasi adalah Kemal Atatruk. Dengan semangat tersebut, pada tahun 1923, Kemal Atatruk melancarkan kudeta sekaligus berhasil merebut kekuasaan dari kerajaan Turki Utsmani. Untuk mewujudkan Westernisasi, Kemal Atatruk melakukan modernisasi atas Turki melalui 6 (enam) poin yang antara lain; pertama, prinsip republik, kedua, nasionalisme, ketiga, prinsip kenegaraan, keempat, prinsip populis yang dimaknai perlindungan hak asasi manusia dan kesetaraan di depan hukum, kelima, sekulerisme, keenam, revolusionisme. ${ }^{19}$

\section{Nasionalisme}

Respon umat Islam berikutnya atas dominasi Barat abad ke-19 adalah nasionalisme. ${ }^{20}$ Sejak pertengahan abad tersebut, paham nasionalis berkembang pesat, meski asal muasal paham tersebut debateble, akan tetapi terdapat kesepakatan bahwa nasionalisme berawal dari Barat, kemudian menyebar ke Timur. Hans Kohn mengartikan nasionalis sebagai kesetiaan tertinggi yang diserahkan kepada negara-bangsa. ${ }^{21}$ Dari pengertian ini maka kesetiaan dijadikan identitas politik bersama serta menentukan tujuan bersama berdasarkan geopolitik mencakup populasi, geografis, dan pemerintahan. Komposisi tersebut inilah yang di sebut dengan negara. Sedangkan Benedict Anderson sebagaimana dikutip Abu Rabi' menyebut nasionalisme sebagai sebuah bangsa atau komunitas politik terbatas, bersatu dan berdaulat. Nasionalisme lebih terbatas dari pandangan tentang umat sebagaimana dalam pengertian Christendom di Kristen dan Ummah di Islam. $^{22}$

Paham nasionalis ini kemudian menjadi pembuka jalan bagi terbentuknya negara-bangsa (nation-state) di dunia Islam. Paham yang dari Barat ini justru memberi dasar di dunia Islam untuk melakukan perlawanan terhadap kolonialisme. Para penggeraknya, berjuang untuk kemerdekaan negaranya dari Barat. Dalam perjuanggannya, mereka sama sekali tidak menggunakan jargon agama, meski mayoritas masayarakatnya adalah Islam, seperti Soekarno di Indonesia, Kemal Ataturk di Turki, Muhammad Ali Jinnah di Pakistan, dan Jamal

${ }^{19}$ Syamsuddin Arif, "Kemodernan, Sekulerisasi dan Agama" dalam Jurnal Pemikiran dan Peradaban Islam: Islamiah, 3, no., 2 (Januari-Maret, 2007): 38.

${ }^{20}$ Abu Rabi', “A Post-September 11”, 24

${ }^{21}$ Hans Kohn, Nasionalism Arti dan Sejarahnya, terj. Sumantri Mertodipuro (Jakarta: PT. Pembangunan dan Erlangga, 1984), 11.

${ }^{22}$ Abu Rabi', “A Post-September 11”, 24 
Abd al-Nasser di Mesir. Hanya saja, menurut Abu Rabi, para tokoh penggerak tersebut masih memuja prestasi ilmiah dan politik Barat. Pendek kata, meskipun mereka berjuang membebaskan dari dominasi politik Barat, namun mereka tetap berupaya membangun masyarakatnya dengan menggunakan filosofi dan cara Barat. ${ }^{23}$

Yang demikian itu, dalam catatan Abu Rabi', nasionalisme yang berkembang di dunia Islam memiliki dua level garapan penting, yaitu spiritual dan institusional. Pada level spiritual, sebagaimana ditunjukkan oleh Partha Chatterjee adalah berusaha untuk mendasarkan kedaulatannya pada kepribadian bangsa, masa lalu, dan identitas kulturalnya. Sementara pada level institusional, adalah mendesain negara dengan cara belajar dan mengadaptasi ilmu pengetahuan beserta bentuk institusi di Barat. ${ }^{24}$

Salah satu potret menarik dari nasionalisme adalah India yang terjadi pada abad 19, di mana para intelektualnya melepaskan diri afiliasi agama, bersatu membersihan India dari dominasi Inggris. ${ }^{25}$ Sayangnya, perjuangan bersama tersebut tidak berlangsung lama, pada tahun 1938, Ali Jinnah (dari Liga Muslim) menutut terpisah sebuah negara muslim dari India. Atas tuntutan tersebut, tahun 1940, Liga Muslim menfasiltasi pembentukan negara Pakistan. ${ }^{26}$ Sebagai negara, Pakistan pada tahun 1971, kehilangan wilayah Pakistan Timur yang kemudian mendirikan negara Bangladesh. ${ }^{27}$

\section{Revivalisme Islam}

Respon ke tiga terhadap tantangan kolonialisasi Eropa adalah revivalisme. Gerakan revivalis di dunia Islam modern menurut Abu Rabi' dapat dibedakan dalam empat kelompok: ${ }^{28}$

${ }^{23}$ Ibid., 24-25.

${ }^{24}$ Ibid., 25.

${ }^{25}$ Ibid.

${ }^{26}$ Terpisahnya Pakistan dari India dari India, membawa pada kebingungan atas identitas sebagai negara yang didirikan untuk muslim India, atau sebagai Negara Islam. Abu al-A'la al-Maududy pada tahun 1941, merespon dengan menyebut the Jama'ah Islamiyyah, dimaksudkan bahwa masa depan Negara Islam tidak boleh dibatasi hanya pada Pakistan. Ibid 25.

${ }^{27}$ Lapidus, A. History of Islamic Societies, 621.

${ }^{28}$ Abu Rabi', “A Post-September 11”, 25. Bandingkan dengan empat tipologi Fazlur Rahman tentang kembangkitan Islam; revivalisme pra-modernis, modernisme klasik, neorevivalisme, neo-modernisme. Taufik Adnan Amal, "Fazlur Rahman dan Usaha-Usaha Neo- 


\section{Pre-colonial}

Revivalisme pra kolonial ditandai Gerakan Wahabi pada awal abad ke-18. Gerakan yang dilekatkan pada sosok Muhammad bin Abdul Wahab (1703-1787) ini hadir sebagai reaksi atas dekadensi internal masyarakat muslim yang diyakini telah melakukan praktik tahayul. Atas dasar itu, Gerakan Wahabiyah melakukan purifikasi terhadap praktik-praktik keagamaan yang menyimpang. Untuk tujuan tersebut, Muhammad bin Abdul Wahab bersekutu dengan penguasa Saudi saat itu. ${ }^{29}$ Di luar gerakan Wahabi di Arab, di India terdapat Syeh Waliyullah, di Afrika terdapat Sanusi dimana mereka memiliki keprihatinan sama dengan gerakan Wahabi, yakni dekadensi sosio-moral masyaralat Islam, sehingga perlu bagi mereka menyerukan kembali kepada Islam sejati, sekaligus memberangus tahayul-tahayul yang telah ditanamkan dalam bentuk-bentuk sufisme. ${ }^{30}$

Ditarik kebelakang, menurut Thoha Hamim kontinuitas seluruh pembaharuan Islam periode ini didasarkan pada gerakan purifikasi Islam yang dibela oleh Ibn Taimiyah (1263-1328 M). Ia beranggapan tidak ada otoritas lain kecuali al-Qur'an, hadis dan praktik salaf. Selanjutnya, Ibn Taimiyah memandang, praktik-praktik kegamaan populer saat itu yang tidak pernah dilakukan oleh Nabi, sahabat dan tabi'in adalah praktik bid'ah. ${ }^{31}$ Buah pikirannya ini teraktualisasi ke dalam hidupnya yang diwujudkan dengan memimpin kampanye melawan berbagai ritus tahayul guna menemukan kembali ruh tauhid. ${ }^{32}$

\section{Colonial Revivalism}

Gerakan Colonial Islamic Revivalism dalam pandangan Abu Rabi' direpresentasikan oleh beberapa organisasi massa yang berdiri pada era kolonialisme. Organisasi tersebut berorientasi pada bidang sosial-keagamaan, antara lain pendidikan Islam, mengontrok kemampanan politik, dan implementasi nilai-nilai syariah ke dalam masyarakat yang lebih luas, seperti organisasi Muhammidiyah dan Nahdlatul

Modernisme Islam Dewasa Ini”, dalam Fazlur Rahman, Metode dan Alternatif NeoModernisme Islam, peny. Taufik Adnan Amal (Bandung: Mizan, 1994), 17-19.

29 Abu Rabi', "A Post-September 11", 25. Lihat juga Khaled Abou Fadl, Selamatkan Islam dari Muslim Puritan, terj. Helmi Mustafa, (Jakarta:Serambi Ilmu Semesta, 2005), 61-92.

30 Taufik Adnan Amal, "Fazlur Rahman dan Usaha-Usaha Neo-Modernisme Islam Dewasa Ini”, 17-18.

31 Thoha Hamim, Paham Keagamaan Kaum Reformis: Studi Kasus Pemikiran Moenawar Chalil, terj. Imron Rosyidi (Yogjakarta: Tiara Wacana, 2000), 11-30.

32 Ibid., 11-12. 


\section{Chafid Wahyudi}

Ulama (NU) di Indonesia yang berdiri pada pertengahan pertama abad ke 20. Di Mesir ada Ikhwanul Muslimin dan Jama'ah Islamiyah di Pakistan yang di komandoi oleh Abu al-A'la al-Maududy di tahun $1941 .^{33}$

Hanya saja, jika melihat era yang dimaksud era kolonial, tulisan artikel Abu Rabi' justru absen menerangkan sosok pembaharu Jamaluddin al-Afghani (18381897) yang telah memperjuangkan konsep ittihad atau wahda, dikenal dengan PanIslamisme (persatuan Islam). Konsep Pan-Islamisme sendiri dapat dikatakan bentuk lain dari kekhalifaan yang mencakup religius, perasaan nasional, dan perlawanan atas Eropa yang disatukan dalam identitas muslim. Sayangnya hingga akhir hayatnya, impian al-Afgani tidak terwujud. Hal mendasar penyebab tidak terwujudnya konsep tersebut adalah Pan-Islamisme dihadapkan pada situasi baru, yaitu tumbuhnya nasionalisme dalam bentuk negara-bangsa. Meski demikian telah memberi pengaruh besar pada tokoh-tokoh pembaharu setelahnya, seperti Muhammad Abduh dan Rasyid Ridha. ${ }^{34}$

\section{Post-Colonial Revivalism}

Gerakan pada era ini muncul sebagai reaksi atas kondisi paska berdirinya negarabangsa di dunia Islam pada pertengahan abad ke 20. Mereka memandang bahwa konsep negara bangsa telah gagal, sehingga mereka perlu melakukan interpretasi ekstrim atas teks agama guna melegitimasi tujuannya, meskipun untuk mencapai melakukannya dengan kekerasan. Seperti peristiwa The Egyptian Jihad di tahun 1970-an dan 1980-an, di Afghanistan terdapat Taliban yang hadir dalam konteks chaos. Saat itu, Afghanistan layaknya negara tidak bertuan setelah Uni Soviet pada akhir tahun 1980-an dan Amerika Serikat di tahun 1990-an yang sebelumnya telah menduduki Afghanistan menarik diri dari wilayah tersebut. Di tengah kekosongan kekuasaan, Taliban hadir menginginkan civil society yang baru. ${ }^{35}$

Menurut Abu Rabi', gerakan Taliban merupakan satu-satunya dalam sejarah Afghanistan modern yang sukses memobilisasi kekerasan untuk mengontrol

${ }^{33}$ Abu Rabi', “A Post-September 11”, 25.

${ }^{34}$ Chafid Wahyudi, NU dan Cilvil Religion: Melacak Akar Civil Religion dalam Keagamaan NU (Yogjakarta: Graha Ilmu, 2013), 28.

${ }^{35}$ Sebagai sebuah fenomena militer dan politik, Taliban adalah sebuah gerakan paska kolonial (post-colonial revivalism). Munculnya Taliban dengan keunggulan militer dan politik harus dikaitkan dengan keterlibatan aktif negara Pakistan dalam urusan internal Afghanistan dan dukungan tentara Pakistan kepada Taliban setelah kelompok-kelompok Mujahidin yang berbeda gagal mencapai kesepakatan tentang masa depan Afghanistan. Abu Rabi', “A Post-September 11” 27. 
masyarakat. Taliban menciptakan suatu masyarakat dan politik baru yang berbasis takut pada Allah. Pada saat yang sama, mencurigai komunisme, kapitalisme, dan Barat, termasuk kaum terpelajar Afghanistan yang dipandang bertanggung jawab mentrasformasikan ide-ide asing sehingga mengakibatkan hancurnya basis tradisional masyarakat Afghanistan. Mereka menyakini bahwa kehadirannya adalah menghentikan kekacauan dalam negeri, menghentikan intervensi asing, serta memulihkan martabat masyarakat Islam. ${ }^{36}$

\section{Post-Nation-State}

Gerakan Osamah bin Laden dengan jaringan Al-Qaeda termasuk kategorikan dalam kelompok ini. Fenomena bin Laden dapat dikatakan merupakan produk ketegangan antara modenisasi Saudi dan nilai-nilai Islam. Saudi di bawah kepemimpinan keluarga kerajaan di tahun 1970-an, telah melakukan modernisasi, tepatnya membaratkan (westernize) masyarakatnya. Modernisasi yang dilakukan keluarga kerajaan Saudi tanpa komponen adat, dan tanpa mempararelkan institusi demokrasi sebagai jaminan masyarakatnya dalam berpartisipasi politik. Meskipun program modernisasi yang dilakukan keluarga kerajaan mendapat dukungan dari para ulama, namun sebagian ulama muda, utamanya dari wilayah Hijaz merasa tidak nyaman dengan langkah modernisasi. Akibatnya, muncul gerakan yang anggap sebagai "Islam ortodok" mewujud dalam gerakan bin Laden. ${ }^{37}$

Selain al-Qaedah, Abu Rabi' juga mengkatagorikan gerakan Taliban dan Jihad Mesir yang sebelumnya juga disebut dalam katagori Post-Colonial Revivalism. ${ }^{38}$ Artinya, gerakan-gerakan ini juga sama-sama merespon negara-bangsa yang diangap sekuler. Selain itu, juga terdapat kesamaan paling tidak pada dua hal: pertama, menghadirkan ortodoksi Islam sebagaimana yang mereka yakini, kedua, militer menjadi sarana kekerasan sosial untuk mencapai tujuannya. Selain itu, gerakangerakan ini tidak mengizinkan menjalankan kebebasan berekspresi di lingkungan demokratis. Sebab bagi mereka, tidak ada norma sepanjang ketidakadilan terjadi di dunia muslim, maka interpretasi atas Islam yang ekstrim akan menjadi norma. ${ }^{39}$

\footnotetext{
${ }^{36}$ Ibid., 26-28.

${ }^{37}$ Ibid.

${ }^{38}$ Ibid., 27.

${ }^{39}$ Ibid., 28
} 


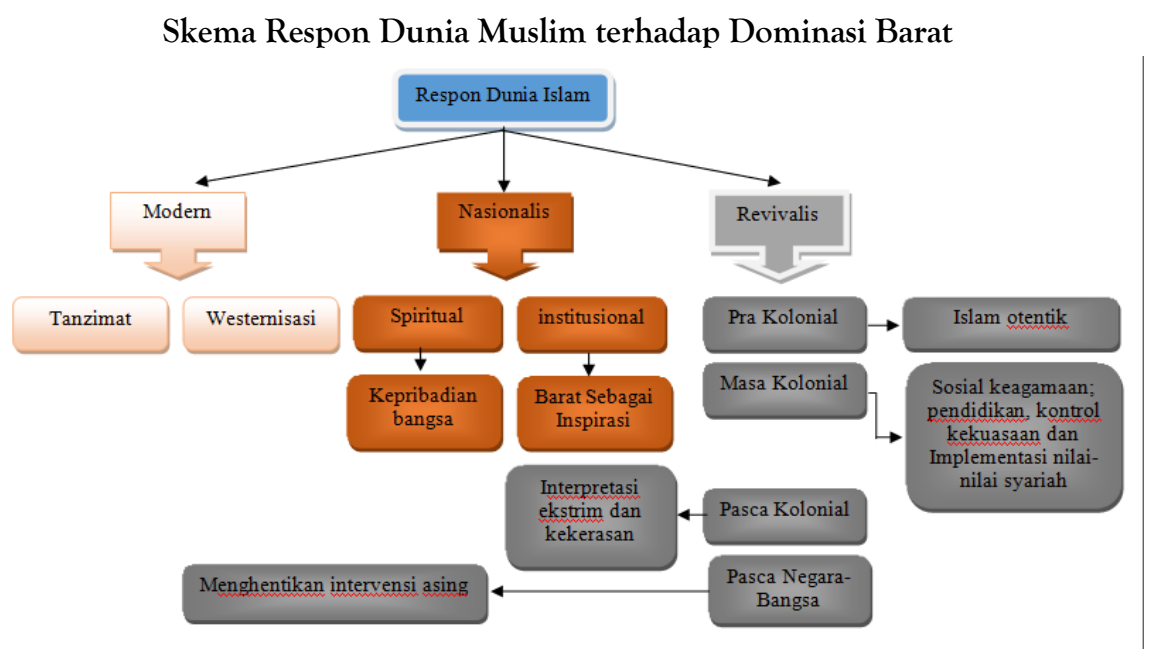

\section{Tawaran Kritik Historis dalam Memodernisasi Pendidikan}

Adalah potret faktual di sebagian negara muslim masih secara tegas menolak modernisasi pendidikan. Abu Rabi' menyebut beberapa alasan modernisasi pendidikan tidak terjadi, lembaga pendidikan tradiosional sengaja dipertahankan oleh para elit militer dan politikus demi kepentingan status quo. Seperti yang terjadi di Pakistan, lembaga pendidikan Islam dengan kurikulum usang, menjadi fokus negara. Pada saat yang sama para ulama memiliki wewenang luar biasa di bawah rezim Zia ul-Haq sejak tahun 1977 hingga 1988. Sebagai gantinya, mereka memberi legitimasi Zia ul-Haq atas Islamisasi di 1980-an. ${ }^{40}$ Kedua, lembaga pendidikan keislaman terbatas pada keilmuan balaghah, nahwu (tata bahasa Arab), syari'ah dan figh, sebaliknya pengembangan kritik atas politik serta aktualitas terhadap situasi kekinian sama sekali tidak dikehendaki. ${ }^{41}$ Hal demikian mematik Malek Bennabi dengan mencemoh silabi dan metode pengajaran pada lembaga

${ }^{40}$ Ibid., 31-2.

${ }^{41}$ Sangat sering, ideologi resmi negara menolak artikulasi kritis atau revolusioner Islam. Yang paling jelas di Arab, di mana dalam departemen teologi gagasan produksi pengetahuan "dianggap menjijikkan" dan hafalan dari teks-teks klasik dijunjung tinggi. Ketidaan treatmen teoritis Islam di dunia muslim ini dapat dideteksi pada konstruksi curricular bidang kajian-kajian keislaman di beberapa universitas Muslim terkemuka seperti Universitas al-Azhar di Mesir, Universitas Imam Ahmad ibn Abd Wahab di Arab Saudi, Dar al-Hadith al-Hassaniyah di Morocco, dan ribuan madrasah tradisional di Asia Selatan khususnya di India, Pakistan, and Afghanistan. Ibid., 32-33. 
Islam secara prinsipil sama dengan umat Kriten Abad Pertengahan. ${ }^{42}$ Ketiga, menempatkan teologi sebatas ritus dan teks-teks sejarah, sama sekali tidak terkait dengan realitas sosial politik. Akibatnya, luaran dari pendidikan Islam tidak mampu mengaktualkan teks secara kritis atas problem sosial dan politik. ${ }^{43}$ Keempat, absennya perspektif ilmu sosial maupun filsafat kritik sebagai perangkat analisis terhadap pemahaman Islam. ${ }^{44}$

Menyikapi borok pendidikan Islam tersebut di atas, Abu Rabi' mengamini usulan pemikir Tunisia, Abdul Majid al-Charfi yang menawarkan pemahaman antara "Islam" dan "Islamic thought" (al-fikr al-Islami). Bagi al-Charfi sebagaimana dikutip abu Rabi', membedakan antara Islam sebagai agama sakral dan Islamic thought sebagai pemikiran Islam yang tidak sakral. Yang terakhir inilah yang menghasilkan berbagai pengetahuan keislaman, seperti tafsir, ilmu hadits, kalam, fiqh, tasawuf, dan lain-lain. ${ }^{45}$ Lebih lanjut, Islam adalah kreasi Tuhan, adapun pemikiran Islam (Islamic thought) adalah kreasi manusia. Islam sebagai agama adalah tunggal, sedangkan pemikiran Islam adalah refleksi dari pemahaman atas Islam pastilah beragam. Islam tidak pernah berubah sedang pemikiran Islam senantiasa berubah, dan Islam sebagai wahyu. ${ }^{46}$ Dari pembedaan pemahaman antara Islam dan Islamic thought al-Charfi, Abu Rabi' mengkritik konsep Islam sebagai "wahyu (revelation)" -didefinisikan oleh 'Al-Charfi,--. Sebab menurut Abu Rabi,' pengertian Islam sesungguhnya berkenaan dengan apa yang dilakukan (Islam is what people make of it). Dengan dasar pemahaman seperti inilah maka Islam dapat menjadi penggerak untuk meraih kemajuan, penyelesaian kesenjangan ekonomi dan sosial. ${ }^{47}$ Lebih lanjut, Abu Rabi' menambahkan perangkat lain di dalam membahas Islam dengan mempertimbangkan hal berikut:

Pertama, berkenaan dengan bidang teologi. Islam sebagai teologi dapat memiliki pengertian yang lebih luas dan terbuka, setidaknya terdapat tiga pengertian; pertama, keesaan Tuhan; kedua, kontinuitas teologis dengan agama wahyu sebelumnya; ketiga, ketundukan kepada keesaan Tuhan (the submission to one God). ${ }^{48}$ Nurcholis Madjid mengartikan Islam dengan "tunduk atau pasrah." Masih

\footnotetext{
${ }^{42}$ Abu Rabi', “A Post-September 11”, 33.

${ }^{43}$ Ibid., 34- 35.

${ }^{44}$ Ibid., 36.

${ }^{45}$ Ibid., 29-30.

${ }^{46}$ Ibid., 30.

47 Ibid.

${ }^{48}$ Ibid.
} 


\section{Chafid Wahyudi}

menurutnya, "pasrah kepada Tuhan" adalah bersifat alami atas manusia, karenanya tidak ada agama tanpa ketundukkan dan kepasrahan, sebaliknya agama tanpa ketundukkan dan kepasrahan kepada Tuhan tidaklah sejati. ${ }^{49}$ Dari beberapa pengertian tersebut, maka seseorang dapat menguji teologi Islam secara inklusif dari perspektif agama-agama wahyu (Abrahamic Religion). Pendek kata, seseorang perlu merangkai teologi keislamannya dengan menghadirkan teologi agama-agama sebelumnya yang tidak lepas keesaan dan ketundukkan/kepasrahan.

Kedua, dominasi teks. Dalam Islam teks begitu dominan. Ali Harb dan Nasr Abu Zayd menyebut, bahwa yang membentuk peradaban Islam adalah peradaban teks. ${ }^{50}$ Kenyataan ini menjadi problem tersendiri dalam Islam. Sebab yang terjadi kemudian adalah sakralitas teks. Abu Rabi' menyebut sejarah pemikiran Islam (turats) tidak lain adalah fiksasi atas perpaduan antara teks keagamaan (religious text) yang berkelindan dengan faktor sosio-ekonomi dan politik, juga perpaduan "ketuhanan" (divine) yang berkelindan dengan "manusia" (human). ${ }^{51}$ Artinya, pembentukan pemikiran Islam terjadi tidak semata sakralitas, unsur keterlibatan manusia berdimensi non sakral meliputi sosio-ekonomi dan politik turut membetuknya. Sehingga hal demikian meniscayakan teks bukan taken for granted. Karenanya, pasca tahun 1967, para intelektual Arab memikirkan kembali keberadaan sakralitas teks yang berkembang di dunia Islam, ${ }^{52}$ seperti Muhammad Arkoun dari Aljazair dan Muhammad Abid al-Jabiri dari Maroko dengan pendekatan post-strukturalis dan dekonstruksi mencoba memahami kembali keberadaan teks-teks klasik warisan Arab-Islam.

Ketiga, fakta antropologi. Salah satu hal yang penting untuk menghadirkan Islam adalah fakta antropologi. Terkait hal tersebut, Abu Rabi' terinspirasi oleh Rochdy Alili tentang Islam normatif dan Islam sebagai fenomena historis. Meski Islam bersumber dari wahyu, namun tidak turun dalam ruang hampa, sebaliknya, terdapat hubungan dialektis antara teks dan realitas sosio-historis. Ketidakhampaan inilah yang pada gilirannya sebagai wujud sejarah evolutifnya, sehingga Islam telah menciptakan tradisi khazanah keilmuan, sosial, dan budaya

${ }^{49}$ Nurcholis Madjid, Islam Doktrin dan peradaban: Sebuah Tela'ah Kritis tentang Masalah Keimanan, Kemanusian dan Kemodernan (Jakarta: Paramadina, 2000), 426-427.

${ }^{50}$ Ali Harb, Hermeneutika Kebenaran, terj. Sunarwoto Dema (Jogjakarta: LKiS, 2003), 31.

${ }^{51}$ Abu Rabi', “A Post-September 11”, 30.
${ }^{52}$ Ibid., 59. 
yang kaya dan beragam. Islam tidak tunggal, melainkan beragam tergantung para intelektual yang menafsirkannya.

Dari pembacaan di atas, di dalam memahami Islam, Abu Rabi' menawarkan kritik historis sebagai separangkat pemahaman atas teologi inklusif, teks dan Sosial-antropologi.

\section{Kritik Historis dalam Studi Islam}

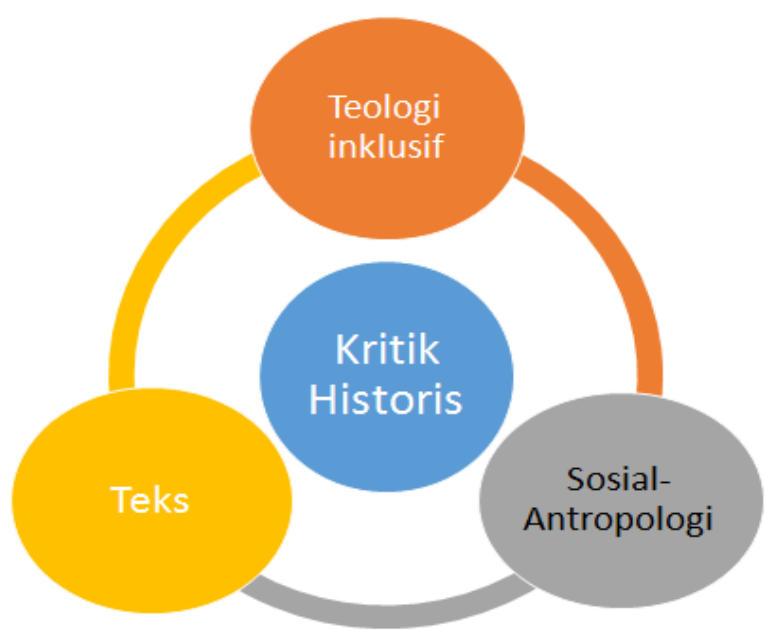

\section{Kesimpulan}

Keterbelakangan dan modernisasi akan terus menjadi perdebatan di dunia Islam. Dinamikanya memberikan respon yang beragam, sebagian menyebut diri dengan identitas sebagai muslim modernis, Islamis revivalistik atau nasionalis untuk merefeleksikan keagamaannya, baik dibidang pendidikan, maupun sosial politiknya. Abu Rabi' sendiri mencoba menyikapi otoritarianisme dalam dunia Islam, khusunya yang berkembang di dunia Arab. Ia menyebut gerakan-gerakan keislaman yang berkembang sebagai respon atas Barat Eropa di beberapa negara muslim gagal menciptakan modernisasi yang baik, seperti pendidikan dan demokrasi. Ibrahim Abu Rabi juga melayangkan kritik atas intervensi Barat yang memicu gerakan radikalisme. Untuk membuka pintu modernisasi, khusunya di pendidikan Islam, Abu Rabi' menawarkan sebuah pendekatan kritik historis dengan memahami secara baik, teologi inklusif, dominasi teks dan agama sebagai fakta sosial-antropologi. 


\section{Referensi}

Amal, Taufik Adnan. "Fazlur Rahman dan Usaha-Usaha Neo-Modernisme Islam Dewasa Ini”, dalam Fazlur Rahman, Metode dan Alternatif Neo-Modernisme Islam, peny. Taufik Adnan Amal. Bandung: Mizan, 1994.

Armando, Nina M.(ed.). Ensiklopedi Islam. Jakarta: Ichtiar Baru van Hoeve, 2005. jilid VII, 69. Nasution, Harun. Pembaharuan dalam Islam Sejarah Pemikiran dan Gerakan. Jakarta: Bulan Bintang, 1992.

Arif, Syamsuddin. "Kemodernan, Sekulerisasi dan Agama" dalam Jurnal Pemikiran dan Peradaban Islam: Islamiah, 3, no., 2 (Januari-Maret, 2007): 38 .

Azra, Azyumardi. Pergolakan Politik Islam; dari Fundamentalisme, Modernitas hingga Post-Modernisme. Jakarta: Paramadina, 1996.

Fadl, Khaled Abou. Selamatkan Islam dari Muslim Puritan, terj. Helmi Mustafa. Jakarta: Serambi Ilmu Semesta, 2005.

Hamim, Thoha. Paham Keagamaan Kaum Reformis: Studi Kasus Pemikiran Moenawar Chalil, terj. Imron Rosyidi. Yogjakarta: Tiara Wacana, 2000.

Harb, Ali. Hermeneutika Kebenaran, terj. Sunarwoto Dema. Jogjakarta: LKiS, 2003.

Huntington, Samuel P. The Clash of civilizations and the Remaking of World Order. London: Simon \& Schulster, 1996.

Kohn, Hans. Nasionalism Arti dan Sejarahnya, terj. Sumantri Mertodipuro. Jakarta: PT. Pembangunan dan Erlangga, 1984.

Lawrence, Bruce B. Islam Tidak Tungggal: Melepaskan Islam Dari Kekerasan, terj. Harimukti Bagoes Oka. Jakarta: Serambi Ilmu Semesta, 2004.

Lapidus, Ira M. A. History of Islamic Societies. New York: Cambridge University Press.

Madjid, Nurcholis. Islam Doktrin dan peradaban: Sebuah Tela'ah Kritis tentang Masalah Keimanan, Kemanusian dan Kemodernan. Jakarta: Paramadina, 2000.

Rabi', Ibrahim M. Abu. "A Post-September 11 Critical Assessment of Modern Islamic History", in September 11: Relegious Perspectives On the Causes and Consequences, Ian Markham and Ibrahim M. Abu-Rabi (eds.). England: Hartford Seminary, 2002.

Wahyudi, Chafid. NU dan Civil Religion: Melacak Akar Civil Religion dalam Keagamaan NU. Yogjakarta: Graha Ilmu, 2013. 
Sumber Web:

Palestine Solidarity Network, Dr. Ibrahim Abu Rabi, http://psnedmonton.ca/2011/07/04/dr-ibrahim-abu-rabi, 30 Oktober 2011 Duncan Black for Macdonald Cente, Faculty Profile of Ibrahim M. Abu Rabi', http://macdonald.hartsem. edu /aburabi.htm. Diakses 31 Oktober 2013.

Intellectual Historian Ibrahim Abu-Rabi' Dies in Amman, http://caroolkersten.blogspot.com/2011/07/ intellectual-historian-ibrahim-abu-rabi.html, diakses 31 Oktober 2013.

International Council For Middle East Studies, Ibrahim M. Abu Rabi' (1956-2011), http://www.icmes.net/?page_id=353, diakses 31 Oktober 2013 